\title{
THE SCIENCE BEHIND THE PERFECT CUP OF COFFEE
}

\author{
WHILE THE DISCIPLINE OF FOOD SCIENCE EMERGED IN THE $20^{\text {TH }}$ \\ CENTURY, FOOD PROCESSING HAS EXISTED IN ONE FORM OR ANOTHER \\ FOR THOUSANDS OF YEARS. THIS COMBINATION OF OLD PROCESSES \\ AND (RELATIVELY) NEW SCIENCES HAS GIVEN US A DAZZLING ARRAY \\ OF FOOD ITEMS TO CHOOSE FROM. DR GABRIEL KEITH HARRIS STUDIES \\ FOOD SCIENCE FOR A LIVING AT NC STATE UNIVERSITY'S FOOD, \\ BIOPROCESSING, AND NUTRITION SCIENCES DEPARTMENT. HIS CURRENT \\ WORK FOCUSES ON COFFEE: ITS CHEMICAL COMPOSITION, FLAVOUR AND \\ SHELF LIFE, AS WELL AS THE USES FOR COFFEE GROUNDS AFTER BREWING
}

\section{FROM BEAN TO CUP}

A coffee plant grows in the tropical sun, its fruit turning a deep red. This plant could be growing in Brazil or Mexico or Ethiopia or Vietnam or any number of places near the equator. While some coffee is grown on large plantations, much of the world's coffee is grown on small farms. Each coffee plant's fruit, called a cherry, contains two coffee beans - its seeds. Ripe, red coffee cherries are harvested and the green beans inside are quickly removed before the fruit spoils. The beans are then fermented, dried, hulled, sorted, placed into plastic and burlap bags, then loaded onto ships to be exported. Roasting turns green coffee beans into the brittle, brown, aromatic beans we are familiar with. Roasted beans are ground and brewed in a variety of ways. Instant coffee is made by freeze drying brewed coffee. Any variation in any stage in this process will affect the end product, by altering the very chemicals that give coffee its distinctive aroma and taste.
Coffee is a popular beverage around the world. About half of consumers drink coffee brewed from grounds. The other half drink instant coffee. In the US, the average coffee consumer drinks over three cups a day - that's 450 million cups daily in the US alone! Coffee has a long and intriguing history stretching back over 1,400 years to its discovery in SubSaharan Africa. It was cultivated and traded on the Arabian Peninsula, then spread to tropical and sub-tropical regions around the world.

Over time, coffee has played an important and sometimes controversial role, at times being promoted and, at other times, being restricted or banned. "The fact that one little bean represents so much historical, economic and cultural change, not to mention microbiology, biochemistry, nutrition, engineering and deliciousness is amazing," says Dr Keith Harris, a food scientist at NC State University in the US. "The best things do come in tiny packages!"

THE JOURNEY TO THE PERFECT BREW Coffee originates from two coffee plant species, Coffea arabica and Coffea canephora, commonly known as Arabica and Robusta. "Arabica beans are less acidic, higher in fat and sugar, and lower in caffeine than Robusta beans," explains Keith. "Robusta beans, on the other hand, contain more acid and caffeine and also come from hardier plants, as the name Robusta implies."

Arabica beans are preferred (and therefore more expensive), due to the milder-

flavoured coffee beverages they produce. Plant genetics, soil quality, soil microbes, weather and altitude all affect the growth of coffee plants. Fermentation, drying, transport, roasting and storage of the beans all affect the flavour of the final brew.

With so many processes involved, a lot can go wrong!

THE CHEMISTRY BEHIND FLAVOUR The Maillard reaction is the key to both flavour and colour development in coffee.

"This is a reaction between sugars and proteins that occurs quickly at high temperatures," says Keith. "It's the same process that makes toast so wonderfully different from untoasted bread." 


\section{KAITH'S TOP TIPS}

- Tour a food factory with your teachers or parents.

- Explore food science as a career option by visiting IFT and food company websites.

- See which universities offer Food Science degrees. (IFT has a webpage dedicated to this: https://www.ift.org/community/ students/undergraduateprograms).

- Reach out to food science professors (like Keith) to get more information: gkharris@ncsu.edu

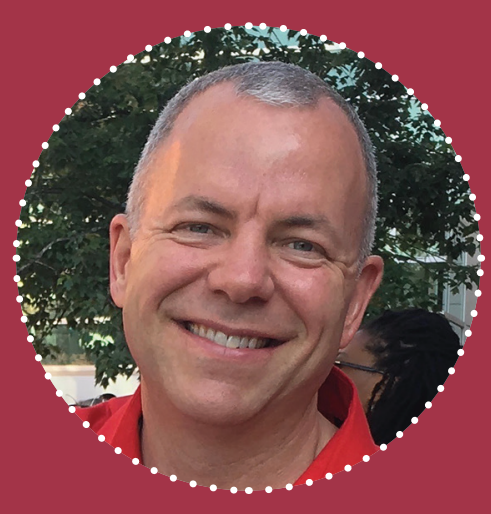

DR GABRIEL KEITH HARRIS

Associate Professor and Undergraduate

Coordinator of Food Science

Food, Bioprocessing, and Nutrition Sciences Department

NC State University, USA

\section{FIELD OF RESEARCH}

Food Science and Nutrition

\section{RESEARGH PROJECT}

Understanding how food processing affects the chemistry and health properties of coffee and other plant foods.

\section{FUNDERS}

US Department of Agriculture, Defence Logistics Agency, State of North Carolina

intriguing usages: removing pollutants from wastewater and replacing flour in brownies.

their flavour and even form objectionable flavours. This process is known as 'fade'. Improper storage can accelerate this process, which is why it is important to store coffee in a cool, dry place away from direct sunlight. Keith's team has been involved in uncovering the optimum conditions for extending shelf life, but this doesn't explain what actually drives the process of fade itself. "The interesting thing about flavour fade is that, although everyone in the coffee industry knows about it, nobody has ever been able to explain it fully," says Keith. "That's what I love about science! There's always a new mystery to tackle."

\section{LESSONS IN EFFICIENCY}

In 2018, the US sent six million tons of 'spent' coffee grounds (left over after brewing) to the landfill. "There are many known uses for spent coffee, including compost, the creation of biodiesel, pressing grounds into logs for firewood, and extracting caffeine for sale," says Keith. His team has investigated two particularly
Keith's team has also looked into more efficient ways of producing cold brew coffee. They found that it takes about twice the amount of coffee to create a similar flavour intensity in cold brewed versus hot water brewed coffee. His lab is working on a process to produce cold brew coffee using less coffee grounds, which could result in savings for the coffee industry.

\section{HEALTH EFFECTS OF CAFFEINE}

Depending on the media source, caffeine (coffee's primary stimulant) could appear to be a miracle cure or a gateway to an early grave. This paradox arises because many factors affect caffeine's stimulant properties. "Positive or negative effects of caffeine are related to the dose, the timing of the dose, and how capable our bodies are of using and getting rid of caffeine," says Keith.

Acute (short-term) positive effects of high doses include sharpened focus on repetitive tasks. Acute negative effects of high doses may include shakiness, palpitations, difficulty sleeping and sometimes a laxative effect. Chronic (long-term) effects of moderate doses, involving weeks to years, are less well understood, but may include reduced risk of diseases like Alzheimer's and Type II diabetes. What constitutes a high dose depends on the person, but according the US Food and Drug Administration', 400 milligrams or four to five cups of coffee per day is considered the limit of a "healthy dose range" for most adults. From its health effects to sustainability to chemistry, who would have thought that a simple coffee bean could teach us so much?

1. https://www.fda.gov/consumers/ consumer-updates/spilling-beanshow-much-caffeine-too-much 


\section{ABOUT FOOD SCIENCE}

Food Science is all about the industrial production of safe, delicious and healthy foods. While the ingredients used are similar to what you might find in your kitchen or at a restaurant, the scale is much, much larger and the processes can be very different. One factory might produce thousands or even millions of food products in a single day. "Food, and the science of food, is so interesting because it applies directly to everyone we meet," says Keith. The food we eat affects our health and wellbeing, as well as playing an important social role. "Our genes determine only part of our destiny. By choosing what we eat and how much, we can have substantial control over our own health."

\section{FOOD SCIENCE AND COVID-19}

The coronavirus pandemic has had profound implications for food production. For example, many countries saw scarcities of certain products during the early stages of the pandemic when demand peaked. Now there may be continued shortage due to the loss of crops and food animals that never made it to market.

For Keith, food safety is a top priority. "Even when COVID-19 is in the past, concerns about the safety of the food we eat will persist. This will be largely in terms of whether a disease-causing organism could be present in a food, but also in terms of the safety of naturally-occurring and added ingredients, as well as food processing." For example, coffee contains both potentially beneficial and potentially harmful compounds in varying quantities. Understanding how all of these compounds interact with our bodies helps us understand the health effects of coffee.

\section{THE FUTURE OF FOOD}

"Looking into the future, food scientists are considering how to effectively feed an ever-growing human population," says Keith.
"Much of that conversation is turning to foods based on plants, fungi and insects, rather than on meat-based products." Meat production generally requires more resources than non-meat alternatives, so it may become a less practical (and more expensive) option as the global population grows and pressure on natural resources increases.

Food science is becoming increasingly sophisticated, opening new doors to producers and consumers alike. "There are also societal questions about food production," says Keith. "For instance, genetic modification remains controversial, despite having support from the majority of scientists (including Keith) as having generally positive effects on food production."

\section{CAREERS IN FOOD SCIENCE}

"I would absolutely recommend a career in food science," says Keith. "It's science you can eat!" There are many jobs that require food scientists, ranging from food safety inspectors to innovators making new foods to chemists that determine the nutritional content of foods. "Food science spans many scientific career paths, from epidemiology to genetics to toxicology and even to space exploration - astronauts have to eat, after all!" says Keith. There are also careers in marketing, business management and logistics within the food industry.

Food science is integral to the food we eat every day. Large-scale production of baked goods, canned foods, chocolate and dairy products would not exist without food science in one form or another. As the world looks to increase the efficiency and capacity of food production and processing at every stage, there will certainly be a need for food scientists for decades to come.

\section{HOW TO BECOME A FOOD SCIENTIST}

- Keith's department (Food, Bioprocessing, and Nutrition Sciences) at NC State University offers undergraduate and graduate degrees in Food Science. They regularly give tours and will visit schools or run video conferences to discuss careers in food science.

- The Institute of Food Technologists (IFT) lists college and universities around the world that offer degrees in Food Science.

- The US Department of Agriculture lists the colleges and universities within the USA that offer food science programmes.

- Leading companies regularly offer food science internships. Examples included Danone, Nestle, The Hershey Company, and Starbucks, as well as many more specialised businesses.

- According to Study.com, food scientists in the US earn on average $\$ 72,570$ per year.

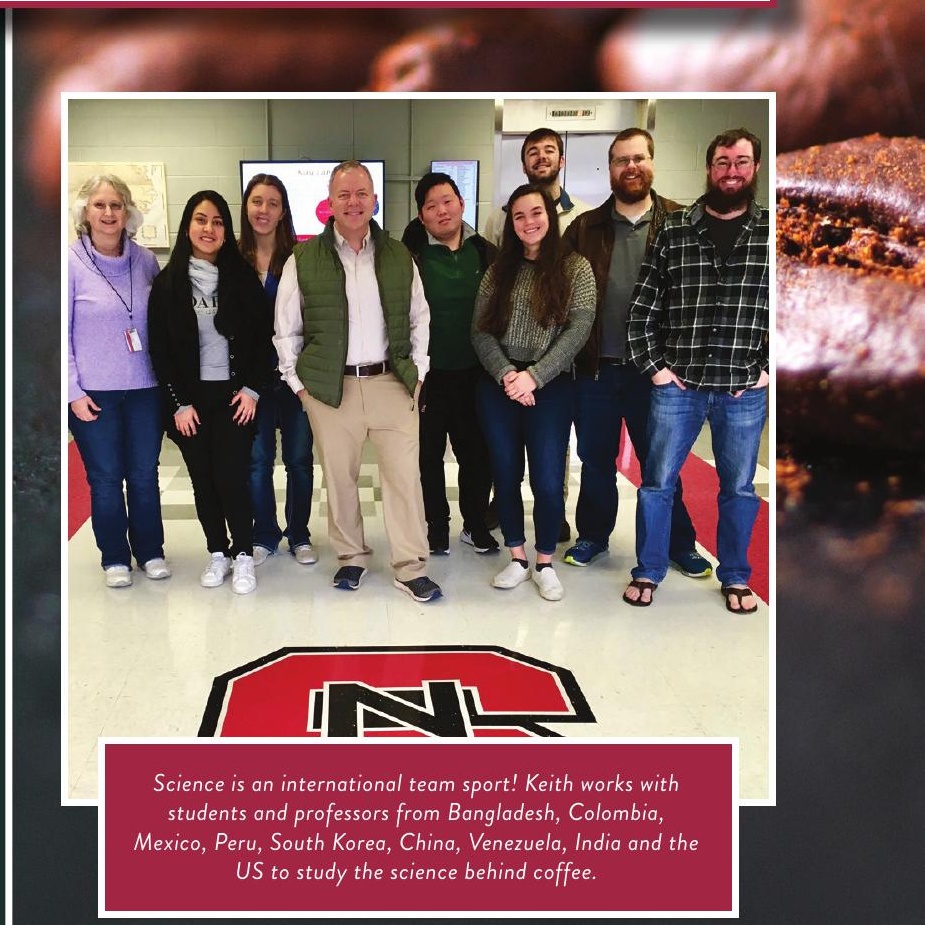




\section{3 HOW DID DR GABRIEL KEITH HARRIS BECOME A FOOD SCIENTIST?}

WHAT INTERESTED YOU WHEN YOU WERE YOUNG? As a child, I loved to read, draw, watch movies and spend time in the forest behind my house climbing trees and searching for interesting creatures.

WHAT ADVICE WOULD YOU GIVE TO YOUR 16-YEAROLD SELF?

I would tell myself that I should look for opportunities that are both fun and that have the possibility of becoming a career; to seek out internships and other practical experiences, rather than simply look for jobs that paid at the time; and that the most important thing is to build good relationships with family and friends, including people who might be able to offer me a job in a few years' time. Being the youngest person on the job can often have advantages. You may be able to ask questions and therefore gain knowledge more quickly than an older person who feels that they 'should know' the answer and, therefore, is reluctant to ask questions.

\section{WHAT ARE YOUR FUTURE AMBITIONS?}

Personally, my ambitions are to be the best father, husband, family member and friend that I can be. I would also love to travel more. So far, my travels have taken me across the US, Mexico and Peru, but the world is so much bigger! Professionally, my ambitions are to advance the careers of as many food science students as possible, to establish bilingual Spanish/English courses and programmes in food science to benefit students across the Americas, and to advance the science of coffee.
WHAT WOULD PEOPLE BE SURPRISED TO KNOW ABOUT YOU?

I am a fairly open person, so there aren't too many surprises. I love talking with friends, reading science fiction books, listening to all kinds of music, distance running, working out, eating ice cream and, of course, drinking coffee. I have a very silly sense of humour, strongly informed by Monty Python. I served in the US Marine Corps and draw on those experiences to provide discipline and determination. I am also a person of faith and I believe the highest good is in serving others.

AND FINALLY, WHAT'S THE SECRET TO THE PERFECT CUP OF COFFEE?

The best cup of coffee in my mind is two tablespoons of dark roast Colombian or Ethiopian coffee, ground finely just as the kettle is about to boil and placed into a conical pour-over funnel lined with a bamboo paper filter. Place the funnel over a large, wide-mouth mug. When the water is just a few degrees below boiling, pour it over the grounds to soak them. Wait 1-2 minutes. Repeat. Extract a third time. The coffee is often too hot to drink immediately, but a wide mouth mug allows you to get your face and nose close enough to enjoy a coffee aromatherapy session that is only surpassed by drinking the coffee itself. This is my very favourite version of a pour-over. The situation is only improved by a good book or a chat with a good friend.

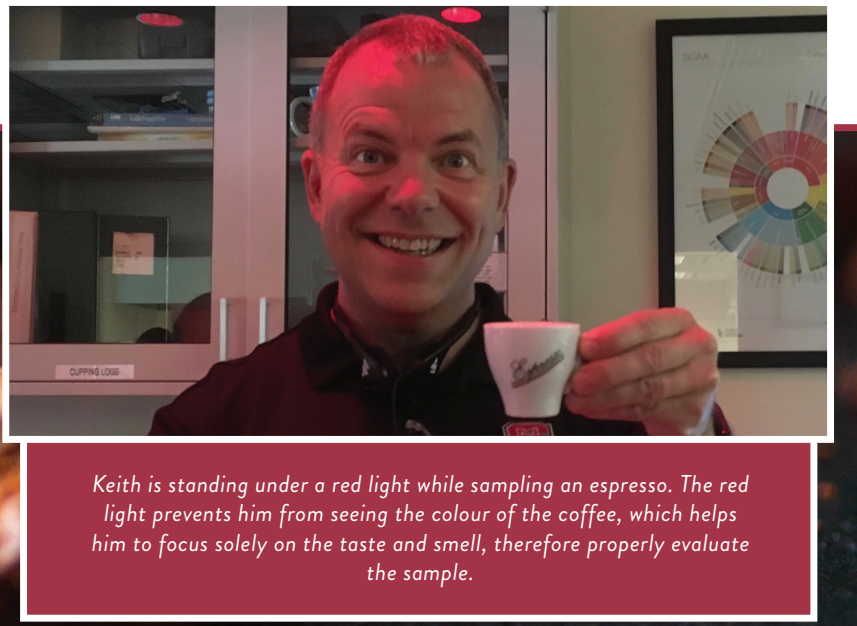

Consider taking biology, chemistry, food technology and engineering courses in high school and at the community college level. Many universities around the world, including NC State, offer undergraduate and graduate degrees in food science.

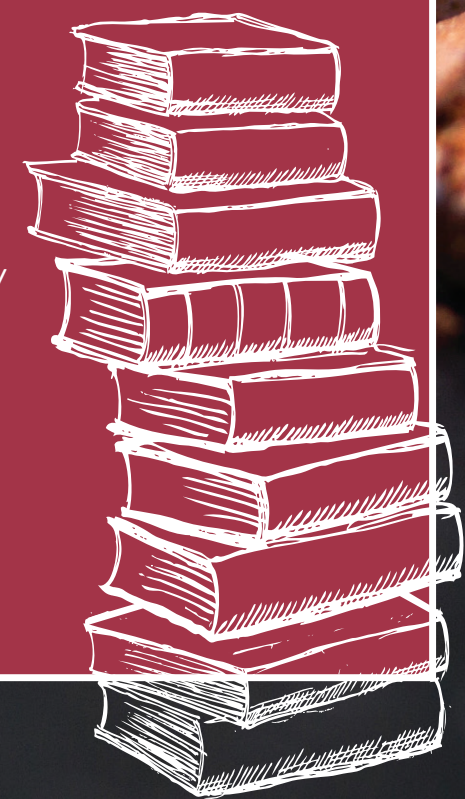

